\title{
Pneumocystis jirovecii İzolatlarının Dihidropteroat Sentaz (DHPS) Gen Mutasyonları ve Mitokondriyal Büyük Alt Birim (mtLSU) rRNA Genotip Varyasyonlarının Belirlenmesi
}

\author{
Dihydropteroate Synthase (DHPS) Gene Mutations and \\ Mitochondrial Large Subunit (mtLSU) rRNA Genotype \\ Variations in Pneumocystis jirovecii Strains
}

\author{
Harun GÜLBUDAK (ID), Candan ÖZTÜRK¹(ID), Sibel KUYUGÖZ²(ID), \\ Seda TEZCAN ÜLGER ${ }^{1}$ (ID) \\ ${ }^{1}$ Mersin Üniversitesi Tıp Fakültesi, Tıbbi Mikrobiyoloji Anabilim Dalı, Mersin. \\ ${ }^{1}$ Mersin University Faculty of Medicine, Department of Medical Microbiology, Mersin, Turkey. \\ ${ }^{2}$ Mersin Üniversitesi Tıp Fakültesi, Enfeksiyon Hastalıkları ve Klinik Mikrobiyoloji Anabilim Dalı, Mersin. \\ ${ }^{2}$ Mersin University Faculty of Medicine, Department of Infectious Diseases and Clinical Microbiology, Mersin, Turkey.
}

\footnotetext{
* Bu çalışma, Mersin Üniversitesi Bilimsel Araştırma Projeleri Birimi tarafından desteklenmiş olup (Proje no: 2017-1-TP32262), Mersin Üniversitesi Tıp Fakültesi, Tıbbi Mikrobiyoloji Anabilim Dalında doktora tezi olarak hazırlanan çalışmanın bir bölümünü oluşturmaktadır.

** Bu çalışma, TMC 2020 Çevrim içi Mikrobiyoloji Sempozyumu (25-27 Aralık 2020, Türkiye)'nda poster olarak sunulmuştur.
}

Makale Atıfı: Gülbudak H, Öztürk C, Kuyugöz S, Tezcan Ülger S. Pneumocystis jirovecii izolatlarının dihidropteroat sentaz (DHPS) gen mutasyonları ve mitokondriyal büyük alt birim (mtLSU) rRNA genotip varyasyonlarının belirlenmesi. Mikrobiyol Bul 2021;55(1):41-52.

\section{ÖZ}

Pneumocystis jirovecii, HIV/AIDS ve immün sistemi baskılanmış hastalarda Pneumocystis pnömonisine $(\mathrm{PCP})$ neden olan atipik bir fungustur. PCP profilaksi ve tedavisinde sülfa ve sülfon grubu içeren ilaçlar yaygın olarak kullanıır. Özellikle trimetoprim sulfametoksazol (TMP-SMX)'un, uzun süreli kullanılması P.jirovecii dihidropteroat sentaz (DHPS) geninde ilaç direnci ile ilişkili belirli nokta mutasyonlara neden olmaktadır. Ayrıca, DHPS ve mitokondriyal büyük alt birim [mitochondrial large subunit (mtLSU)] rRNA genotip karakterizasyonu P.jirovecii epidemiyolojisi hakkında önemli veri sağlamaktadır. Bu çalışmada, Mersin Üniversitesi Hastanesinde, immün sistemi baskılanmış hastalardan izole edilen P.jirovecii izolatlarının DHPS ve mtLSU rRNA gen bölgesi polimorfizmlerinin araştırılması amaçlanmıştır. Bu çalışmaya, Ağustos 2016-Şubat 2018 tarihleri arasında 96 hasta örneğinden mtLSU-rRNA nested PCR ile pozitif bulunan 16 P.jirovecii örneği dahil edilmiştir. P.jirovecii mtLSU rRNA genotipleri dizi analizi yapılarak 85 . ve 248. nükleotit pozisyonundaki polimorfizmlere göre belirlenmiştir. DHPS bölgesi, 165. ve 171. nükleotit pozisyonları mutasyon analizi için nested PCR ve RFLP yöntemi uygulanmıştır. DHPS mutasyon analizinde 16 P.jirovecii örneğinin 12 (\%75)'sinde vahşi tip (W165/W171), 4 (\%25)'ünde ise mutant tip (M165/ W171) tespit edilmiştir. Mutant tiplerin ikisi PCP ve HIV/AIDS tanısı ve profilaksi öyküsü olan; diğer ikisi kolonizasyon tespit edilen hasta örnekleridir. Çalışmadaki 16 hastanın 3 (\%19)'ünde profilaksi öyküsü 
kaydedilmiş ve bu 3 hastanın ikisinde mutant tip saptanmıştır. mtLSU-rRNA analizine göre 16 P.jirovecii izolatından 3 farklı genotip elde edilmiştir. Bölgemizde en sık genotip $2 \% 43.75(n=7)$, ikinci sıklıkta genotip $1 \% 37.5(n=6)$ ve en az genotip $3 \% 18.75(n=3)$ tespit edilmiştir. Bölgemizde genotip 4 görülmemiştir. DHPS ve mtLSU-rRNA multilokus olarak değerlendirildiğinde beş farklı genotip gözlenmiştir. Sonuç olarak, bu bulgular bölgemizdeki P.jirovecii epidemiyolojisi hakkında önemli veriler sağlamış ve potansiyel ilaç dirençli suşların immünsupresif hastalarda bulaş riski taşıdığını göstermiştir. Bölgemizde ve ülkemizde P.jirovecii epidemiyolojisini daha iyi tanımlayabilmek için daha fazla P.jirovecii izolatını içeren çok merkezli çalışmalara gereksinim vardır.

Anahtar kelimeler: Pneumocystis jirovecii; dihidropteroat sentaz (DHPS) mutasyonu; mtLSU rRNA analizi; genotiplendirme.

\section{ABSTRACT}

Pneumocystis jirovecii is an atypical fungus that causes Pneumocystis pneumonia (PCP) in HIV/AIDS and immunocompromised patients. Antibiotics containing sulfa and sulfone groups are widely used in PCP prophylaxis and treatment. Especially, long-term use of trimethoprim sulfamethoxazole (TMP-SMX) is known to cause certain point mutations associated with drug resistance in the P.jirovecii dihydropteroate synthase (DHPS) gene. In addition, DHPS and mitochondrial large subunit (mtLSU) rRNA genotype characterization provides important data on the epidemiology of P.jirovecii. In this study, it was aimed to investigate the DHPS and mtLSU rRNA gene polymorphisms of P.jirovecii strains isolated from immunocompromised patients in Mersin University Hospital. In this study, 16 P.jirovecii positive samples, which isolated from 96 patients samples, between August 2016 and February 2018, were included. P.jirovecii mtLSU rRNA genotypes were determined by sequence analysis according to polymorphisms at the $85^{\text {th }}$ and $248^{\text {th }}$ nucleotide positions. Nested PCR and RFLP method was applied for mutation analysis of DHPS locus, $165^{\text {th }}$ and $171^{\text {st }}$ nucleotide positions. In the DHPS mutation analysis, 12/16 (75\%) wild type (W165/W171) and 4/16 (25\%) mutant type (M165/W171) were detected. Two mutant types belonged to HIV/AIDS positive patients with PCP and had a history of prophylaxis; the other 2 mutant types belonged to patients with colonization. In the study, a history of prophylaxis in $3(19 \%)$ of the 16 patients were recorded, and mutant type was detected in these 2 of 3 patients. According to mtLSU-rRNA analysis, 3 different genotypes were obtained from 16 P.jirovecii isolates. In our region, genotype $2(43.75 \% ; n=7)$ was the most common genotype, genotype $1(37.5 \% ; n=6)$ was the second common and genotype $3(18.75 \% ; n=3)$ was the least one. Genotype 4 was not detected in our region. When DHPS and mtLSU-rRNA were evaluated as multilocus, five different genotypes were observed. As a result, these findings provided important data on P.jirovecii epidemiology in our region and potential drug-resistant strains showed a risk of transmission in immunosuppressive patients. Multicenter studies involving more P.jirovecii isolates are needed to better define the epidemiology of P.jirovecii in our region and in our country.

Keywords: Pneumocystis jirovecii; dihydropteroate synthase (DHPS) mutation; mtLSU rRNA analysis; genotyping.

\section{Giriş}

Pneumocystis jirovecii, önceki adıyla Pneumocystis carinii, immün sistemi baskılanmış hastalarda fırsatçı enfeksiyona neden olan atipik bir fungustur ${ }^{1}$. P.jirovecii enfeksiyonu kistlerin solunum yoluyla alınması sonucu bulaşmakta ve genellikle asemptomatik seyretmektedir. Ancak immünsupresif hastalarda ve özellikle AIDS'lilerde ciddi pnömoniye neden olmaktadır ${ }^{1,2}$. Pneumocystis pnömonisi (PCP), önceki yıllarda insan immün yetmezlik virüsü/kazanılmış immün yetmezlik sendromu (HIV/AIDS) ilişkili bir hastalık olarak bilinirken, günümüzde profilaksi ve antiretroviral tedavi ile birlikte AIDS ilişkili PCP insidansı büyük oranda azalmış; kemoterapi, kortikosteroid ve antirejeksiyon gibi immün sistemi baskılayıc tedavi alan hasta sayısının artmasıyla, HIV negatif hastalarda daha yaygın hale gelmiştir². 
PCP'den korunma ve tedavide, sülfa ve sülfon grubu içeren ilaçlar yaygın olarak kullanılmaktadır. Trimetoprim-sulfametoksazol (TMP-SMX), PCP profilaksi ve tedavisinde kullanılan primer ilaçtır ${ }^{3,4}$. Sülfametoksazol, para-aminobenzoik asidin (PABA) yapısal analoğu olup PABA, folat sentez yolunun temel bileşeni olan dihidropteroat sentaz (DHPS) enziminin doğal substratıdır ${ }^{4,5}$. P.jirovecii'de, DHPS enzimini kodlayan folik asit sentez (fas) genindeki iki sinonim olmayan nokta mutasyon, sülfa türevi ilaçlara önceden maruz kalma ile ilişkilidir ${ }^{4,6-8}$. DHPS bölgesi $165(A \rightarrow G)$ ve $171(C \rightarrow T)$ nükleotit pozisyonlarında meydana gelen bu mutasyonlar, enzimin aktif bölgesindeki proteinde, 55 (Thr $\rightarrow$ Ala) ve 57 (Pro $\rightarrow$ Ser) amino asit dizilerinde, yapısal değişime neden olmaktadır ${ }^{4,5,9}$. Sülfa türevi ilaçların bağlanma bölgesinde meydana gelen değişiklikler ilacın afinitesini ve inhibitör etkisini azaltarak, tedavi ve profilakside başarısızlığa neden olur ${ }^{4,6,8}$. P.jirovecii kültür yöntemleri ile üretilemediği için, ilaç direnci çalışmaları DHPS lokus mutasyon analizine dayanmaktadır ${ }^{4}$.

P.jirovecii genotipleri ve DHPS mutant suşların dağılımı coğrafik bölgelere ve şehirlere göre farklılık göstermektedir ${ }^{10}$. P.jirovecii genotip karakterizasyonu için DHPS lokus polimorfizmi dışında mitokondriyal büyük alt birim (mitochondrial large subunit, mtLSU) rRNA, "internal transcribed spacer (ITS)" 1 ve 2, sitokrom b ve süperoksit dismutaz gibi farklı lokusların hedeflendiği moleküler tiplendirme yöntemleri kullanılmaktadır ${ }^{10-12}$. Bu yöntemler arasında mtLSU rRNA ve ITS lokusları en sık kullanılan gen bölgeleridir. MtLSU rRNA tiplendirme için bildirilen polimorfizm miktarı ITS'den daha azdır, ancak gözlenen varyasyonlar, epidemiyolojik soruların ele alınmasında yararlıdır. Bu yöntem, amplifikasyon ve sekans analizine dayanır, genotipler 85. ve 248. nükleotit pozisyonlarındaki polimorfizmlere göre belirlenmektedir ${ }^{10,11}$.

Moleküler tiplendirme çalışmaları P.jirovecii'nin insandan insana bulaş sonucu yayılabileceğini gösterir ${ }^{13}$. Bu yüzden, DHPS bölge mutasyon analizi yapılması ve mtLSU rRNA genotiplerinin belirlenmesi, P.jirovecii potansiyel ilaç direnci ve epidemiyolojisi hakkında veri sağlar. Bu çalışmada, Mersin Üniversitesi Hastanesinde, immün sistemi baskılanmış hastalardan izole edilen P.jirovecii suşlarının DHPS bölge mutasyonları ve mtLSU rRNA gen bölgesi polimorfizmlerinin araştırılması amaçlanmıştır.

\section{GEREÇ ve YÖNTEM}

Bu çalışma, Mersin Üniversitesi Klinik Araştırmalar Etik Kurulu onayı ile gerçekleştirildi (Tarih: 09.06.2016 ve Karar no: 2016/177).

\section{Hastalar ve Örnekler}

Bu çalışmaya, Ağustos 2016-Şubat 2018 tarihleri arasında Mersin Üniversitesi Hastanesinde, \%75'i immün sistemi baskılayıcı tedavi alan 96 hasta örneğinden (88 balgam, 6 trakeal aspirat ve 2 bronkoalveolar lavaj) "mtLSU-rRNA nested" polimeraz zincir reaksiyonu (PCR) sonucu pozitif olan 16 P.jirovecii DNA örneği dahil edildi ${ }^{14}$. Çalışmaya dahil edilen hastaların 11 (\%69)'i erkek, 5 (\%31)'i kadın ve yaş ortalaması $61 \pm 12$ (yaş aralığı; 40-82) idi. Hastaların altta yatan hastalıklara göre dağılımı ise; altısı kanser, üçü hemato- 
lojik malignite, üçü HIV/AIDS, ikisi kronik obstruktif akciğer hastalığı (KOAH) ve ikisi intersitisyel akciğer hastalığı şeklindeydi. On altı hastanın on biri (\%68.75) immünsupresif tedavi alan (biri HIV pozitif non-Hodgkin lenfoma), üçü (\%18.75) immünkompetan ve diğer ikisi (\%12.5) yalnızca HIV/AIDS'ti. P.jirovecii tespit edilen hastalarda PCP, olası PCP ve kolonizasyon gibi enfeksiyonun klinik olarak sınıflandırılması daha önce araştırmacılar tarafından kullanılan kriterlere dayanarak; mikroskopi, PCR, klinik ve radyolojik bulgulara göre yapıldı ${ }^{15,16}$. Buna göre, P.jirovecii saptanan hastaların beşi kesin PCP (HIV/AIDS, $n=$ 3; akciğer kanseri, $n=1$; interstisyel akciğer hastalığı, $n=1$ ); üçü olası PCP (multipl myelom, $n=1$; interstisyel akciğer hastalığı, $n=1$; kolanjiosellüler karsinom, $n=1$ ) ve sekizi kolonizasyon olarak tanımlandı ${ }^{14}$.

\section{P.jirovecii mtLSU-rRNA PCR ve Genotip Analizi}

Mukoid yapıda olan solunum yolu örnekleri, \%0.3'lük 1,4-dithiothreitol (DTT) ile muamele edilerek homojenize hale getirildi. Örneklerin DNA izolasyonu "QIAamp DNA blood mini kit" (Qiagen, Almanya) ile kan ve vücut sıvılarından DNA izolasyon protokolü uygulanarak yapıldı.

P.jirovecii mtLSU rRNA gen bölgesini hedefleyen nested PCR yönteminde birinci tur PCR için pAZ102-E ve pAZ102-H; ikinci tur PCR için pAZ102-X ve pAZ102-Y primerleri kullanıld ${ }^{17}$. Her bir örneğin PCR amplifikasyonu $50 \mu l^{\prime}$ lik reaksiyon hacminde gerçekleştirildi. Birinci tur için PCR reaksiyon karışımı; $5 \mu \mathrm{l}$ 10XPCR tampon, $2 \mu \mathrm{mol} / \mu \mathrm{l} \mathrm{MgCl}_{2}, 0.2$ $\mu \mathrm{mol} / \mu \mathrm{l}$ dNTP karışımı, $0.25 \mathrm{pmol} / \mu \mathrm{l}$ her bir primer, $1.25 \mathrm{U}$ Taq DNA polimeraz ve $8 \mu \mathrm{l}$ kalıp DNA'sı içermektedir. İkinci tur PCR bileşenleri benzer şekilde hazırlandı ve birinci tur PCR ürününden $3 \mu$ örnek, kalıp DNA olarak kullanıldı. Örneklerin amplifikasyon koşulları birinci tur için; $94^{\circ} \mathrm{C}^{\prime}$ de 5 dakika başlangıç denatürasyonu, arkasından 40 döngü $94^{\circ} \mathrm{C}^{\prime}$ de 1 dakika denatürasyon, $55^{\circ} \mathrm{C}^{\prime}$ de 1 dakika bağlanma ve $72^{\circ} \mathrm{C}^{\prime}$ de 1.5 dakika uzama basamakları ve arkasından $72^{\circ} \mathrm{C}^{\prime}$ de 5 dakika son uzama basamağı şeklinde uygulandı. İkinci tur amplifikasyon için primer bağlanma sıcaklığı $50^{\circ} \mathrm{C}$ olacak şekilde aynı termal döngü koşulları kullanıldı. Birinci ve ikinci tur PCR ürünlerinden sırasıyla 346 ve 263 baz çifti (bp) uzunluğunda bant elde edilen örnekler pozitif olarak değerlendirildi.

İkinci tur PCR amplifikasyon ürünlerine "Bigdye terminator v3.1 cycle sequencing" (Applied Biosystems, ABD) kit kullanılarak dizi analizi gerçekleştirildi. Dizi analizi verileri ABI PRISM 3130XL Genetic Analyzer (Applied Biosystems, ABD) kromatogram şeklinde toplandı. Dizi analizi sonuçları Chromas programı (Versiyon 2.6.6 Technelysium Pty Ltd, Avustralya) ile değerlendirildi. Elde edilen diziler ve referans Pneumocystis dizisi (Genbank accession number M58605.1) ${ }^{18}$, çoklu gen hizalama programı olan Clustal X (Versiyon 2.1, İrlanda) ile karşılaştıııldı ve genotip analizi 85. ve 248. nükleotit pozisyonundaki polimorfizmlere göre yapıldı.

Genotip analiz değerlendirmesi Pneumocystis mtLSU-rRNA genotipleri daha önce tanımlanmış polimorfizmlere göre yapıldı; genotip 1: $85 \mathrm{C} / 248 \mathrm{C}$, genotip 2: $85 \mathrm{~A} / 248 \mathrm{C}$, genotip 3: $85 \mathrm{~T} / 248 \mathrm{C}$ ve genotip 4: $85 \mathrm{C} / 248 \mathrm{~T}$ şeklindedir ${ }^{10}$. 


\section{DHPS Gen Bölgesi PCR ve Mutasyon Analizi}

Çalışmada, DHPS bölge mutasyon analizi için ilk olarak DHPS gen bölgesini hedefleyen nested PCR yöntemi uygulandı. Birinci tur PCR için F1 (5'-CCT GGT ATT AAA CCA GTT TTG CC-3') ve B45 (5'-CAA TTT AAT AAA TTT CTT TCC AAA TAG CAT C-3'); ikinci tur PCR için AHUM (5'-GCG CCT ACA CAT ATT ATG GCC ATT TTA AAT C-3') ve BN (5'GGA ACT TTC AAC TTG GCA ACC AC-3') primerleri kullanıldı ${ }^{9}, 10$. Her bir örneğin PCR amplifikasyonu $50 \mu \mathrm{l}^{\prime}$ lik reaksiyon hacminde gerçekleştirildi. Birinci tur PCR için reaksiyon karışımı; $5 \mu \mathrm{l}$ 10X PCR tamponu, $2 \mu \mathrm{mol} / \mu \mathrm{l} \mathrm{MgCl}_{2}, 0.2 \mu \mathrm{mol} / \mu \mathrm{l}$ dNTP karışımı, 0.25 $\mathrm{pmol} / \mu \mathrm{l}$ her bir primer, 1.25 U Taq DNA polimeraz ve $6 \mu$ örnek DNA'sı içermektedir. İkinci tur PCR bileşenleri benzer şekilde hazırlandı ve birinci tur amplifikasyon ürününden $3 \mu$ örnek, kalıp DNA olarak kullanıldı.

Termal döngü profili, ilk tur için 40 döngü, ikinci tur için 35 döngü olarak uygulandı. Örneklerin amplifikasyon koşulları birinci tur için; $94^{\circ} \mathrm{C}^{\prime}$ de 5 dakikalık başlangıç denatürasyonu, ardından 40 döngü; $94^{\circ} \mathrm{C}^{\prime}$ de 1 dakika denatürasyon, $53^{\circ} \mathrm{C}$ 'de 1 dakika bağlanma ve $72^{\circ} \mathrm{C}^{\prime}$ de 1.5 dakika uzama basamakları ve arkasından $72^{\circ} \mathrm{C}^{\prime}$ de 5 dakika son uzama basamağı şeklinde uygulandı. İkinci tur amplifikasyon için primer bağlanma sıcaklığı $55^{\circ} \mathrm{C}$ olacak şekilde aynı termal döngü programı kullanıldı.

Amplifikasyon ürünleri, $0.5 \mu \mathrm{g} / \mathrm{ml}$ etidyum bromür içeren \%1'lik agaroz jelde 120 voltta 40 dakika elektroforez uygulandıktan sonra ultraviyole altında görüntülendi. Birinci ve ikinci tur PCR ürünlerinden beklenen bantlar sırasıyla, 895 ve 371 bp uzunluğundadır ${ }^{9}$.

DHPS gen bölgesi mutasyon analizi için, ikinci tur PCR ürünlerine, Accl (Thermo scientific, $A B D$ ) ve Haelll (Thermo scientific, $A B D$ ) restriksiyon enzimleri kullanılarak "restriction fragment length polymorphism (RFLP)" yöntemi uygulandı. RFLP reaksiyonu, her bir örnek için Accl ve Haell enzimi ile iki ayrı $21 \mu \mathrm{l}$ hacimli (9 $\mu$ l PCR ürünü, $2 \mu \mathrm{l}$ 10Xbuffer, $9 \mu \mathrm{l}$ steril distile su ve $1 \mu \mathrm{l}$ restriksiyon enzimi [10U/ $\mu \mathrm{l}$ stok]) reaksiyon karışımı hazırlandı, örnekler $37^{\circ} \mathrm{C}^{\prime}$ de 16 saat inkübe edildikten sonra $80^{\circ} \mathrm{C}^{\prime}$ de 20 dakika termal inaktivasyon uygulandı. RFLP reaksiyonu ile kesim işlemi yapılan ürünler, etidyum bromür içeren $\% 2^{\prime}$ lik agaroz jelde 120 voltta 50 dakika elektroforeze tabi tutulduktan sonra ultraviyole ışık altında görüntülendi. Çalışmada restriksiyon analizi üç defa tekrar edilerek doğrulandı.

Mutasyon analiz değerlendirmesi DHPS gen bölgesindeki 165. (Kodon 55) ve 171. (Kodon 57) nükleotit pozisyonlarındaki olası mutasyonlar elektroforez görüntülerinden elde edilen restriksiyon profillerine göre yapıldı. Mutasyonların restriksiyon enzim aktivitesini inhibe etmeleri nedeniyle, Accl enzimi ile reaksiyona giren örnek kodon 55 mutasyonu olmayan vahşi tip (W165) ise, 229 ve 142 bp uzunluğunda iki bant oluştururken; mutasyon (M165) varlığında 371 bp uzunluğunda kesilmemiş tek DNA parçası olarak kalmaktadır. Haelll enzimi ile reaksiyona giren örnek kodon 57 mutasyonu olmayan vahşi tip (W171) ise 221, 131 ve 19 bp uzunluğunda üç bant oluşturur, ancak en küçük parçanın elektroforezde görüntülememesi nedeniyle iki bant görülmektedir. Mutasyon (M171) varlığında ise 352 ve 19 bp uzunluğunda iki bant izlenmektedir 9 . 


\section{BULGULAR}

Çalışmaya dahil edilen 16 P.jirovecii pozitif hasta örneğinin tamamından mtLSU-rRNA genotipleri ve DHPS gen bölgesi mutasyon analizi sonuçları elde edilmiştir.

Genotip analizi, mtLSU-rRNA bölgesi 85. ve 248. nükleotit pozisyonlarındaki polimorfizme göre yapılmıştır. On altı P.jirovecii izolatından üç farklı genotip elde edilmiştir. Genotip dağılımına göre bölgemizde en yaygın görülen genotip; (\%43.75, n= 7) genotip $2(85 \mathrm{~A} / 248 \mathrm{C})$ olurken, ikinci sıklıkta $(\% 37.5, \mathrm{n}=6)$ genotip $1(85 \mathrm{C} / 248 \mathrm{C})$ ve üçüncü sıklıkta (\%18.75, n= 3) genotip 3 (85T/248C) tespit edilmiştir (Tablo I). Bölgemizde genotip $4(85 T / 248 T)$ görülmemiştir.

DHPS gen bölgesi 165. (kodon 55) ve 171. (kodon 57) nükleotit pozisyonlarına göre 16 P.jirovecii örneğinin 12 (\%75)'sinde mutasyon bulunmayan vahşi tip (W165/W171), 4 (\%25)'ünde ise mutant tip (M165/W171) tespit edilmiştir (Şekil 1, Tablo II). Mutant tip tespit edilen hastaların ikisinin PCP'si olan HIV/AIDS hastası ve profilaksi öyküsü olan hastalar olduğu saptanmıştır. Mutant tip bulunan diğer iki hastanın ise P.jirovecii kolonizasyonu tanımlanan, biri lenfoma tanılı kemoterapi tedavisi almış ve diğeri akciğer kanseri tanısı konmuş hastalar olduğu tespit edilmiştir. Çalışmadaki 16 hastanın 3 (\%19)'ünde profilaksi öyküsü olduğu görülmüş ve bu 3 hastanın ikisinde mutant tip saptanmıştır.

\begin{tabular}{|lcc|}
\hline \multicolumn{4}{|l|}{ Tablo I. P.jirovecii mtLSU-rRNA Genotip Analizi } \\
\hline MtLSU-rRNA Genotipleri & Nükleotit pozisyonları & Hasta sayısı $\mathbf{n = 1 6}(\%)$ \\
\hline 1 & $85 / C ; 248 / C$ & $6(37.5)$ \\
2 & $85 / A ; 248 / C$ & $7(43.75)$ \\
3 & $85 / T ; 248 / C$ & $3(18.75)$ \\
4 & $85 / C ; 248 / \mathrm{T}$ & - \\
\hline
\end{tabular}

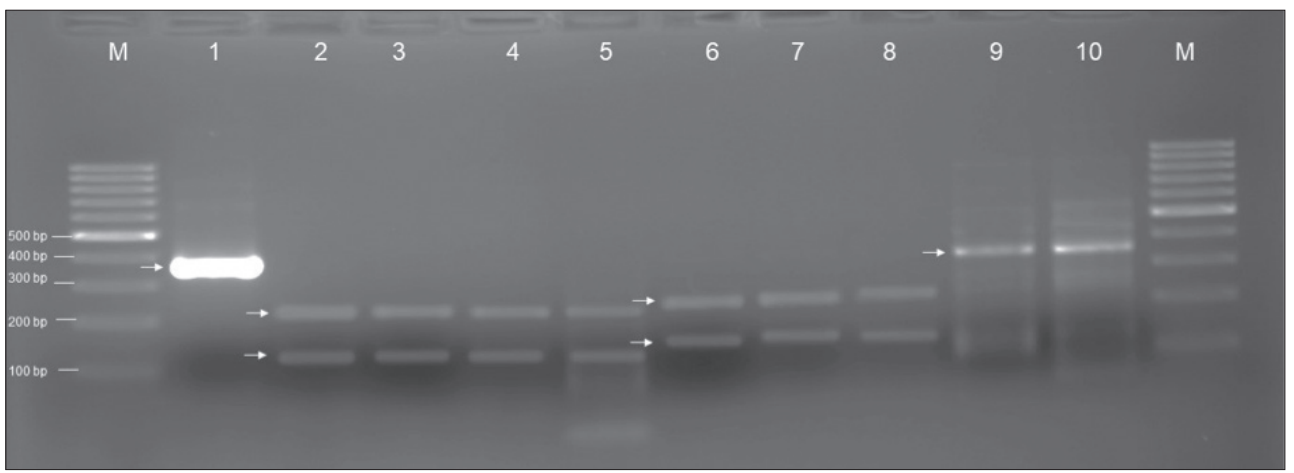

Şekil 1. P.jirovecii DHPS gen bölgesi PCR RFLP agaroz jel elektroforez görüntüsü. Kolon M: Moleküler ağırlık belirteci (GeneRuler 100 bp Plus DNA Ladder, Thermo Scientific); Kolon 1: DHPS nested PCR ikinci tur amplifikasyon ürünü (371 bp); Kolon 2-5: Haelll ile wild tip örneğin enzimatik kesim reaksiyon ürünü (221 bp, 131 bp). Kolon 6-8: Accl ile wild tip örneğin enzimatik kesim reaksiyon ürünü (229 bp, 142 bp). Kolon 9-10: Accl ile mutant tip örneğin enzimatik kesim reaksiyon sonucu (371 bp). 


\begin{tabular}{|c|c|c|c|c|}
\hline \multicolumn{2}{|c|}{ DHPS genotipler } & \multicolumn{2}{|c|}{ Nükleotit (Aminoasit) } & \multirow[t]{2}{*}{ Hasta sayısı $n=16(\%)$} \\
\hline & & $165(55)$ & $171(57)$ & \\
\hline 1 & Vahşi tip (W165/W171) & A (Thr) & C (Pro) & $12(75)$ \\
\hline 2 & Mutant tip (M165/W171)a & G (Ala) & $C($ Pro) & $4(25)$ \\
\hline 3 & Mutant tip (W165/M171) & $\mathrm{A}(\mathrm{Thr})$ & $\mathrm{T}(\mathrm{Ser})$ & 0 \\
\hline 4 & İkili mutant tip (M165/M171) ${ }^{c}$ & G (Ala) & $\mathrm{T}($ Ser $)$ & 0 \\
\hline \multicolumn{5}{|c|}{$\begin{array}{l}\text { DHPS: Dihidropteroatesentaz. } \\
\text { a: Mutant tip; } 165 \text {. nükleotit pozisyonunda ( } 55 \text {. aminoasit pozisyonu) mutasyon. } \\
\text { b: Mutant tip; } 171 \text {. nükleotit pozisyonunda ( } 57 \text {. aminoasit pozisyonu) mutasyon. } \\
\text { c: İkili mutant tip; } 165 \text {. ve } 171 \text {. nükleotit pozisyonunda mutasyon olan mutant tip. }\end{array}$} \\
\hline
\end{tabular}

DHPS ve mtLSU-rRNA lokusları birlikte multilokus olarak değerlendirildiğinde iki bölgesinin olası 16 genotip kombinasyonundan beşi gözlenmiştir. Multilokus genotipler (mtLSU/DHPS); G2/G1 6 (\%37.5), G1/G1 3 (\%18.75), G1/G2 3 (\%18.75), G3/G1 3 (\%18.75) ve G2/G2 1 (\%6.25) olarak gözlenmiştir. En yaygın multilokus genotip, her bir lokustaki en yaygın genotip kombinasyonlarından elde edilmiştir (Tablo III).

\section{TARTIŞMA}

Mikroorganizmaların epidemiyolojik bulaş yollarının tespit edilmesi hastalığa karşı kontrol önlemleri geliştirmek açısından önemlidir. Moleküler genotiplendirme çalışmaları, P.jirovecii genotiplerinin coğrafik bölgelere ve şehirlere göre farklılık gösterdiğini ortaya koymuştur ${ }^{10}$. Ayrıca, hastalardan izole edilen genotiplerin hastaların doğduğu şehirle ilişkili olmadığı, hastanın yaşadığı şehir ya da tanının konduğu yer ile ilişsili olduğu bildirilmiştir ${ }^{10}$. Translasyon sırasında mitokondriyal ribozoma peptidil transferaz aktivitesi sağlayarak temel metabolik mekanizmalarda rol oynayan, mtLSU rRNA geni, farklı coğrafi bölgelerden P.jirovecii izolatlarının genetik karakterizasyonu için yaygın olarak kullanılmaktadır ${ }^{11}$. Bu çalışmada, mtLSU-rRNA bölgesi 85 . ve 248. nükleotit pozisyonlarındaki polimorfizme göre 16 P.jirovecii izolatından üç farklı genotip elde edilmiştir. Bölgemizde genotip 2 ( $n=7 ; \% 43.75$ ) en yaygın görülen genotip olurken, ikinci sıklıkta genotip 1 ( $n=$ $6 ; \% 37.5)$ ve en az genotip $3(n=3 ; \% 18.75)$ tespit edilmiştir. Ülkemizden daha önce bildirilen mtLSU-rRNA genotiplendirme çalışmasına rastlanmamıştır. Farklı coğrafyalardaki çalışmalarda İtalya, Polonya ve Küba'dan bu çalışmadaki genotip dağılımına benzer şekilde genotip 2 en sık, genotip 1 ikinci sıklıkta ve genotip 3 üçüncü sıklıkta bildirilmiş$\operatorname{tir}^{12,19,20}$. Hindistan'da genotip 2 en sık ve İran'da ise ikinci sıklıkta tespit edilmiştir ${ }^{21,22}$. ABD, İspanya, Portekiz ve Kore'de genotip 1 en sık görülen P.jirovecii genotipidir ${ }^{10,11,23,24}$. Genotip dağılımındaki bu farklı epidemiyolojik bulgular, P.jirovecii'deki genetik varyasyonların coğrafik bir bileşene sahip olduğunu ve P.jirovecii suşlarının insanlar arasındaki sirkülasyonunu etkileyebileceğini göstermektedir.

TMP-SMX, PCP profilaksi ve tedavisinde ilk seçenek ilaçtır ${ }^{3}$. Ancak, sülfa grubu ilaçların yaygın olarak kullanılması tedavi ve profilakside başarısızlığa neden olan mutasyonlara yol 
Pneumocystis jirovecii Izolatlarının Dihidropteroat Sentaz (DHPS) Gen Mutasyonları ve Mitokondriyal Büyük Alt Birim (mtLSU) rRNA Genotip Varyasyonlarının Belirlenmesi

\begin{tabular}{|c|c|c|c|c|c|c|}
\hline Hasta no & $\begin{array}{l}\text { Örnek } \\
\text { tarihi }\end{array}$ & Klinikler & $\begin{array}{l}\text { MtLSU } \\
\text { rRNA tip }\end{array}$ & DHPS tip & Profilaksi & $\begin{array}{c}\text { Multilokus } \\
\text { mtLSU/DHPS }\end{array}$ \\
\hline 2 & 21.02 .2017 & $\begin{array}{l}\text { Nefroloji } \\
\text { servisi }\end{array}$ & $85 C / 248 C$ & M165/W171 & - & $\mathrm{G} 1 / \mathrm{G} 2$ \\
\hline 6 & 11.01 .2018 & $\begin{array}{l}\text { Göğüs } \\
\text { Hastalıkları } \\
\text { servisi }\end{array}$ & $85 C / 248 C$ & M165/W171 & - & $\mathrm{G} 1 / \mathrm{G} 2$ \\
\hline 8 & 31.03 .2017 & $\begin{array}{l}\text { Enfeksiyon } \\
\text { servisi }\end{array}$ & $85 C / 248 C$ & M165/W171 & Var & $\mathrm{G} 1 / \mathrm{G} 2$ \\
\hline 20 & 06.02 .2017 & $\begin{array}{l}\text { Hematoloji } \\
\text { servisi }\end{array}$ & $85 C / 248 C$ & W165/W171 & - & G1/G1 \\
\hline 28 & 24.11 .2016 & $\begin{array}{l}\text { Hematoloji } \\
\text { servisi }\end{array}$ & $85 C / 248 C$ & W165/W171 & - & G1/G1 \\
\hline 32 & 02.12 .2016 & $\begin{array}{l}\text { Göğüs } \\
\text { Hastalıkları } \\
\text { servisi }\end{array}$ & $85 C / 248 C$ & W165/W171 & - & $\mathrm{G} 1 / \mathrm{G} 1$ \\
\hline 56 & 27.04 .2017 & $\begin{array}{l}\text { Göğüs } \\
\text { Hastalıkları } \\
\text { servisi }\end{array}$ & $85 \mathrm{~A} / 248 \mathrm{C}$ & W165/W171 & - & G2/G1 \\
\hline 62 & 09.03 .2017 & $\begin{array}{l}\text { Onkoloji } \\
\text { servisi }\end{array}$ & $85 A / 248 C$ & W165/W171 & - & G2/G1 \\
\hline 68 & 11.01 .2018 & $\begin{array}{l}\text { Onkoloji } \\
\text { servisi }\end{array}$ & $85 \mathrm{~A} / 248 \mathrm{C}$ & W165/W171 & - & G2/G1 \\
\hline 73 & 04.04 .2017 & $\begin{array}{c}\text { Enfeksiyon } \\
\text { YBÜ }\end{array}$ & $85 A / 248 C$ & W165/W171 & Var & G2/G1 \\
\hline 86 & 04.05 .2017 & $\begin{array}{l}\text { Göğüs } \\
\text { Hastalıkları } \\
\text { servisi }\end{array}$ & $85 \mathrm{~A} / 248 \mathrm{C}$ & W165/W171 & - & $\mathrm{G} 2 / \mathrm{G} 1$ \\
\hline 90 & 07.02 .2017 & $\begin{array}{l}\text { Onkoloji } \\
\text { servisi }\end{array}$ & $85 \mathrm{~A} / 248 \mathrm{C}$ & W165/W171 & - & G2/G1 \\
\hline 98 & 28.02 .2018 & $\begin{array}{l}\text { Enfeksiyon } \\
\text { servisi }\end{array}$ & $85 A / 248 C$ & M165/W171 & Var & $\mathrm{G} 2 / \mathrm{G} 2$ \\
\hline 60 & 06.02 .2017 & $\begin{array}{l}\text { Göğüs } \\
\text { Hastalıkları } \\
\text { servisi }\end{array}$ & $85 \mathrm{~T} / 248 \mathrm{C}$ & W165/W171 & - & $\mathrm{G} 3 / \mathrm{G} 1$ \\
\hline 70 & 20.03.2017 & $\begin{array}{c}\text { Göğüs } \\
\text { Hastalıkları } \\
\text { servisi }\end{array}$ & $85 \mathrm{~T} / 248 \mathrm{C}$ & W165/W171 & - & $\mathrm{G} 3 / \mathrm{G} 1$ \\
\hline 85 & 22.04 .2017 & $\begin{array}{l}\text { Göğüs } \\
\text { Hastalıkları } \\
\text { servisi }\end{array}$ & $85 \mathrm{~T} / 248 \mathrm{C}$ & W165/W171 & - & $\mathrm{G} 3 / \mathrm{G} 1$ \\
\hline
\end{tabular}


açmaktadır ${ }^{4,6-8}$. P.jirovecii kültür yöntemleri ile üretilemediği için, ilaç direnci çalışmaları DHPS bölge mutasyon analizine dayanmaktadır. Dünya genelinde \%0-81 arasında değişen P.jirovecii DHPS mutasyon oranı bildirilmiştir ${ }^{4}$. Çalışmamızda, P.jirovecii tespit edilen 16 hastanın 12 (\%75)'sinde vahşi tip (W165/W171), 4 (\%25)'ünde mutant tip (M165/ W171) tespit edilmiştir. On altı hastanın 3 (\%19)'ünde profilaksi öyküsü vardır ve bu üç hastanın ikisinde mutant tip saptanmıştır. Mutant tip tespit edilen hastaların ikisi PCP tanısı olan HIV pozitif ve profilaksi öyküsü olan hastalardır. Mutant tip bulunan diğer iki hasta ise P.jirovecii kolonizasyonu tanımlanan, biri lenfoma tanılı kemoterapi tedavisi almış ve diğeri akciğer kanseri tanısı konmuş hastalardır. Ülkemizden DHPS mutasyonu araştırılan sadece bir çalışma bildirilmiştir. Özkoç ve arkadaşları İzmir'de yaptıkları çalışmada ${ }^{25}$ DHPS amplifikasyonu elde edilen 28 P.jirovecii örneğinin tamamını vahşi tip olarak tespit etmişler ve mutasyon bildirmemişlerdir.

Gelişmiş ülkelerde yapılmış çalışmalarda daha yüksek mutasyon oranı bildirilmiştir. ABD'de HIV pozitif PCP'li hastalardan izole edilen P.jirovecii örnekleri ile yapılan çalışmalarda \%81'e ulaşan mutasyon oranı bildirilmiştir ${ }^{6-8,10}$. Avrupa ülkelerinde; Fransa'dan \%3-33, İspanya'dan \%22-28, İtalya'dan \%0-9, İsviçre'den \%7.5, Portekiz'den \%7, Almanya'dan \%1.2 ve İsveç'ten 0 oranında mutasyon bildirilmiştir ${ }^{5,9,11,19,26-29}$. Gelişmekte olan ülkelerde ise, Güney Afrika'dan \%56, Şili'den \%48, İran'dan \%14.7, Çin'den \%12, Tayland'dan \%11.7 ve Hindistan'dan \%4.1 oranında DHPS mutasyonu bildirilmiştir ${ }^{30-35}$.

Yapılan çalışmalarda, profilaksi ve HIV pozitif hasta sayısı arttıkça mutasyon oranlarının da artış gösterdiği görülmüştür ${ }^{6-8}$. Ancak bazı çalışmalarda, daha önce profilaksi ilaç kullanmamış hastalarda da mutant tiplerin tespit edildiği bildirilmiştir ${ }^{7,27,30}$. Son yıllarda Ponce ve arkadaşları Şili'de yaptıkları çalışmada ${ }^{30}$, daha önce sülfa türevi profilaksi ilaç kullanmamış 56 hastanın 27 (\%48)'sinde mutant suş tespit ettiklerini bildirmişlerdir. Ülkemizde HIV/AIDS ve organ transplant alıcıları dışındaki, immünsupresif hastalarda sulfonamit profilaksisi rutin olarak uygulanmamaktadır ${ }^{25,36}$. Çalışmamızda, profilaksi öyküsü olan 3 HIV/AIDS pozitif hastanın ikisinde mutant tip saptanmıştır ve toplam 4 mutant suşun ikisinin HIV/AIDS pozitif hastalarda profilaksi sonucu meydana geldiği görülmüştür. Mutant tip saptanan diğer iki hasta ise P.jirovecii kolonizasyonu tanımlanan, biri lenfoma tanılı kemoterapi tedavisi almış ve diğeri akciğer kanseri tanısı konmuş hastalardır. Mutant suş ile meydana gelen enfeksiyonlarda en önemli risk etmeni profilaksi süresinin artması sayılırken, mutant suşların coğrafik dağılımına bağlı olarak, bireylerin yaşadığı şehir ve ülke gibi coğrafik etkenler ya da başvurulan hastane ortamı, mutant suşların alınmasındaki önemli risk faktörleri arasındadır $6,7,10,27,30$.

Bazı çalışmalar, PCP'nin latent enfeksiyonun reaktivasyonu yerine nozokomiyal bulaş sonucu gelişen, yeni kazanılan bir enfeksiyon olduğunu göstermiştir. Çeşitli moleküler yöntemlerle belirlenen aynı genotiplerle kümelenme veya salgın suşları, P.jirovecii'nin insandan insana bulaş sonucu yayılabileceğini göstermiştir ${ }^{13,24,37}$. Bu çalışmada DHPS ve mtLSUrRNA genetik lokusları multilokus olarak değerlendirildiğinde beş genotip gözlenmiştir. Multilokus genotiplerde (mtLSU/DHPS); G2/G1'de 6, G1/G1'de 3, G1/G2'de 3, G3/G1'de 3, G2/G2' de 1 suş küme oluşturmuştur. Bu bulgulara göre, çalışma süresi boyunca, hasta- 
nemizde beş farklı P.jirovecii genotipinin dağılım gösterdiği ve bunlardan ikisinin (G1/G2, G2/G2) potansiyel ilaç direncine sahip DHPS mutant tiplerden oluştuğu ortaya konmuştur.

Spor tuzakları ile yapılan çalışmalar Pneumocystis'in çevresel kaynaklardan yayılabileceğini göstermiştir ancak memeli konaklar dışında rezervuar tanımlanmamıştır ${ }^{38}$. Bu yüzden, P.jirovecii toplumda rezervuar olarak bulunabilir ve immün sistemi baskılanmış bir konağa ulaşıncaya kadar kişiden kişiye bulaşarak subklinik kolonizasyona neden olarak yayılabilir ${ }^{13,39}$. PCP'li hastalar enfeksiyon sırasında etkeni solunum yoluyla havaya yayar $^{40}$. Bir hava örnekleme çalışmasında, $P C P^{\prime} l i$ hastaların bulunduğu servislerden ve bitişik koridorlardan alınan hava örnekleri analiz edildiğinde PCP'li hastaların 8 m'ye kadar uzağında P.jirovecii tespit edilmiş, ayrıca servise bitişik koridorlarda da Pneumocystis pozitifliğinin devam ettiği görülmüştür ${ }^{40}$. Başka bir çalışmada, Pneumocystis enfeksiyonu olmayan hastaların bulunduğu yoğun bakım ünitelerinden ve hastanedeki boş odalardan alınan hava örneklerinde de Pneumocystis saptanmıştır ${ }^{41}$. PCP'li hastaların havaya Pneumocystis'i yayması sonucu, bu hastalar ile ilgilenen doktor, hemşire ve hasta yakınlarının P.jirovecii ile kolonize olduğu gösterilmiştir ${ }^{37}$. Bu çalışmada, elde edilen verilere göre hastanemizde beş farklı P.jirovecii genotipi immünsupresif hastalarda bulaş riski oluşturmaktadır ve bunlardan ikisi potansiyel ilaç direncine sahiptir.

Sonuç olarak, çalışmada P.jirovecii tespit edilen 16 hastanın 4 (\%25)'ünde potansiyel ilaç direncini gösteren DHPS mutant tipi (M165/W171) tespit edilmiştir. mtLSU rRNA genotip analizinde üç farklı genotip elde edilmiş ve bölgemizde G2 ve G1 en yaygın görülen genotip olarak belirlenmiştir. Bu bulgular bölgemizdeki P.jirovecii epidemiyolojisi hakkında önemli veriler sağlamış ve potansiyel ilaç dirençli suşların immünsupresif hastalarda bulaş riski taşıdığını göstermiştir. Bölgemizde ve ülkemizde P.jirovecii epidemiyolojisini daha iyi tanımlayabilmek için daha fazla P.jirovecii izolatını içeren çok merkezli çalışmalara gereksinim bulunmaktadır.

\section{ETIK KURUL ONAYI}

Bu çalışma, Mersin Üniversitesi Klinik Araştırmalar Etik Kurulu onayı ile gerçekleştirildi (Tarih: 09.06.2016 ve Karar no: 2016/177).

\section{ÇIKAR ÇATIŞMASI}

Yazarlar bu makale ile ilgili herhangi bir çıkar çatışması bildirmemişlerdir.

\section{KAYNAKLAR}

1. Calderon EJ, Varela JM, Durand-Joly I, Dei-Cas E. Pneumocystis jirovecii pneumonia, pp: 1-36. In: Saurez ML, Ortega SM (ed), Pneumonia: Symptoms, diagnosis and treatment. 2011, Nova Science Publishers Inc: NY, USA.

2. Liu Y, Su L, Jiang SJ, Qu H. Risk factors for mortality from Pneumocystis carinii pneumonia (PCP) in non-HIV patients: A meta-analysis. Oncotarget 2017; 8(35): 59729-39.

3. Limper AH, Knox KS, Sarosi GA, Ampel NM, Bennett JE, Catanzaro A, et al. An official American Thoracic Society statement: Treatment of fungal infections in adult pulmonary and critical care patients. Am J Respir Crit Care Med 2011; 183(1): 96-128. 
4. Matos O, Esteves F. Epidemiology and clinical relevance of Pneumocystis jirovecii Frenkel, 1976 dihydropteroate synthase gene mutations. Parasite 2010; 17(3): 219-32.

5. Beser J, Dini L, Botero-Kleiven S, Krabbe M, Lindh J, Hagblom P. Absence of dihydropteroate synthase gene mutations in Pneumocystis jirovecii isolated from Swedish patients. Med Mycol 2012; 50(3): 320-3.

6. Kazanjian P, Armstrong W, Hossler PA, Burman W, Richardson J, Lee $\mathrm{CH}$, et al. Pneumocystis carinii mutations are associated with duration of sulfa or sulfone prophylaxis exposure in AIDS patients. J Infect Dis 2000; 182(2): 551-7.

7. Huang L, Beard CB, Creasman J, Levy D, Duchin JS, Lee S, et al. Sulfa or sulfone prophylaxis and geographic region predict mutations in thePneumocystis carinii dihydropteroate synthase gene. J Infect Dis 2000; 182(4): $1192-8$.

8. Crothers K, Beard CB, Turner J, Groner G, Fox M, Morris A, et al. Severity and outcome of HIV-associated Pneumocystis pneumonia containing Pneumocystis jirovecii dihydropteroate synthase gene mutations. AIDS 2005; 19(8): 801-5.

9. Le Gal S, Damiani C, Perrot M, Rouillé A, Virmaux M, Quinio D, et al. Circulation of Pneumocystis dihydropteroate synthase mutants in France. Diagn Microbiol Infect Dis 2012; 74(2): 119-24.

10. Beard CB, Carter JL, Keely SP, Huang L, Pieniazek NJ, Moura IN, et al. Genetic variation in Pneumocystis carinii isolates from different geographic regions: implications for transmission. Emerg Infect Dis 2000; 6(3): 26572.

11. Esteves F, Montes-Cano MA, de la Horra C, Costa MC, Calderón EJ, Antunes F, et al. Pneumocystis jirovecii multilocus genotyping profiles in patients from Portugal and Spain. Clin Microbiol Infect 2008; 14(4): 356-62.

12. Sokulska M, Kicia M, Wesolowska M, Piesiak P, Kowal A, Lobo ML, et al. Genotyping of Pneumocystis jirovecii in colonized patients with various pulmonary diseases. Med Mycol 2018; 56(7): 809-15.

13. Yiannakis EP, Boswell TC. Systematic review of outbreaks of Pneumocystis jirovecii pneumonia: evidence that P.jirovecii is a transmissible organism and the implications for healthcare infection control. J Hosp Infect 2016; 93(1): 1-8.

14. Gülbudak H, Öztürk C, Kuyugöz S, Tezcan Ülger S. Investigation of Pneumocystis jirovecii infection and colonization in immunocompromised patients with pneumonia. Mikrobiyol Bul 2020; 54(4): 583-95.

15. Maillet M, Maubon D, Brion JP, François P, Molina L, Stahl JP, et al. Pneumocystis jirovecii (Pj) quantitative PCR to differentiate Pj pneumonia from Pj colonization in immunocompromised patients. Eur J Clin Microbiol Infect Dis 2014; 33(3): 331-6.

16. Özkoç S, Bayram Delibaş S. Investigation of Pneumocystis jirovecii pneumonia and colonization in iatrogenically immunosuppressed and immunocompetent patients. Mikrobiyol Bul 2015; 49(2): 221-30.

17. Tamburrini E, Mencarini P, Visconti E, Zolfo M, De Luca A, Siracusano A, et al. Detection of Pneumocystis carinii DNA in blood by PCR is not of value for diagnosis of P. carinii pneumonia. J Clin Microbiol 1996; 34(6): 1586-8.

18. Sinclair K, Wakefield AE, Banerji S, Hopkin JM. Pneumocystis carinii organisms derived from rat and human hosts are genetically distinct. Mol Biochem Parasitol 1991; 45(1): 183-4.

19. Dimonte S, Berrilli F, D'Orazi C, D'Alfonso R, Placco F, Bordi E, et al. Molecular analysis based on mtLSU-rRNA and DHPS sequences of Pneumocystis jirovecii from immunocompromised and immunocompetent patients in Italy. Infect Genet Evol 2013; 14: 68-72.

20. Monroy-Vaca EX, de Armas Y, Illnait-Zaragozí MT, Toraño G, Diaz R, Vega D, et al. Prevalence and genotype distribution of Pneumocystis jirovecii in Cuban infants and toddlers with whooping cough. J Clin Microbiol 2014; 52(1): 45-51.

21. Gupta R, Mirdha BR, Guleria R, Agarwal SK, Samantaray JC, Kumar L, et al. Genotypic variation of Pneumocystis jirovecii isolates in India based on sequence diversity at mitochondrial large subunit rRNA. Int J Med Microbiol 2011; 301(3): 267-72.

22. Fata A, Abdollahi B, Rezaeetalab F, Attaran D, Najjari M, Najafzadeh MJ. Molecular diagnosis and genotyping of Pneumocystis jirovecii in bronchoalveolar lavage samples obtained from patients with pulmonary disorder. Curr Med Mycol 2019; 5(3): 13-8. 
Pneumocystis jirovecii İzolatlarının Dihidropteroat Sentaz (DHPS) Gen Mutasyonları ve Mitokondriyal Büyük Alt Birim (mtLSU) rRNA Genotip Varyasyonlarının Belirlenmesi

23. Montes-Cano MA, de la Horra C, Martin-Juan J, Varela JM, Torronteras R, Respaldiza N, et al. Pneumocystis jiroveci genotypes in the Spanish population. Clin Infect Dis 2004; 39(1): 123-8.

24. Kim T, Lee SO, Hong HL, Lee JY, Kim SH, Choi SH, et al. Clinical characteristics of hospital-onset Pneumocystis pneumonia and genotypes of Pneumocystis jirovecii in a single tertiary centre in Korea. BMC Infect Dis 2015; 15: 102.

25. Ozkoc S, Erguden C, Bayram Delibas S. Absence of dihydropteroate synthase gene mutations in Pneumocystis jirovecii strains isolated from Aegean region of Turkey. Parasitol Res 2018; 117(10): 3103-8.

26. Hauser PM, Nahimana A, Taffe P, Weber R, Francioli P, Bille J, et al. Interhuman transmission as a potential key parameter for geographical variation in the prevalence of Pneumocystis jirovecii dihydropteroate synthase mutations. Clin Infect Dis 2010; 51(4): e28-33.

27. Friaza V, Morilla R, Respaldiza N, de la Horra C, Calderón EJ. Pneumocystis jirovecii dihydropteroate synthase gene mutations among colonized individuals and Pneumocystis pneumonia patients from Spain. Postgrad Med 2010; 122(6): 24-8.

28. Valerio A, Tronconi E, Mazza F, Fantoni G, Atzori C, Tartarone F, et al. Genotyping of Pneumocystis jiroveci pneumonia in Italian AIDS patients. Clinical outcome is influenced by dihydropteroate synthase and not by internal transcribed spacer genotype. J Acquir Immune Defic Syndr 2007; 45(5): 521-8.

29. Suárez I, Roderus L, van Gumpel E, Jung N, Lehmann C, Fätkenheuer G, et al. Low prevalence of DHFR and DHPS mutations in Pneumocystis jirovecii strains obtained from a German cohort. Infection 2017; 45(3): 341-7.

30. Dini L, du Plessis M, Frean J, Fernandez V. High prevalence of dihydropteroate synthase mutations in Pneumocystis jirovecii isolated from patients with Pneumocystis pneumonia in South Africa. J Clin Microbiol 2010; 48(6): 2016-21.

31. Ponce CA, Chabé M, George C, Cárdenas A, Durán L, Guerrero J, et al. High prevalence of Pneumocystis jirovecii dihydropteroate synthase gene mutations in patients with a first episode of Pneumocystis pneumonia in Santiago, Chile, and clinical response to trimethoprim-sulfamethoxazole therapy. Antimicrob Agents Chemother 2017; 61(2): e01290-16.

32. Sheikholeslami MF, Sadraei J, Farnia P, Forozandeh Moghadam M, Emadikochak H. Dihydropteroate synthase gene mutation rates in Pneumocystis jirovecii strains obtained from Iranian HIV-positive and nonHIV-positive patients. Med Mycol 2015; 53(4): 361-8.

33. Deng X, Zhuo L, Lan Y, Dai Z, Chen WS, Cai W, et al. Mutational analysis of Pneumocystis jirovecii dihydropteroate synthase and dihydrofolate reductase genes in HIV-infected patients in China. J Clin Microbiol 2014; 52(11): 4017-9.

34. Siripattanapipong S, Leelayoova S, Mungthin M, Worapong J, Tan-Ariya P. Study of DHPS and DHFR genes of Pneumocystis jirovecii in Thai HIV-infected patients. Med Mycol 2008; 46(4): 389-92.

35. Tyagi AK, Mirdha BR, Luthra K, Guleria R, Mohan A, Singh UB, et al. Pneumocystis jirovecii dihydropteroate synthase (DHPS) genotypes in non-HIV-immunocompromised patients: a tertiary care reference health centre study. Med Mycol 2011; 49(2): 167-71.

36. Boğa C, Bolaman Z, Çağırgan S, Karadoğan I, Özcan MA, Özkalemkaş F, et al. Recommendations for risk categorization and prophylaxis of ınvasive fungal diseases in hematological malignancies: a critical review of evidence and expert opinion (TEO-4). Turk J Haematol 2015; 32(2): 100-17.

37. Vargas SL, Ponce CA, Gigliotti F, Ulloa AV, Prieto S, Muñoz MP, et al. Transmission of Pneumocystis carinii DNA from a patient with P. carinii pneumonia to immunocompetent contact health care workers. J Clin Microbiol 2000; 38(4): 1536-8.

38. Wakefield AE. DNA sequences identical to Pneumocystis carinii f. sp. carinii and Pneumocystis carinii f. sp. hominis in samples of air spora. J Clin Microbiol 1996; 34(7): 1754-9.

39. Qoraan I, Oz Y, Metintas M, Durmaz G. The investigation of Pneumocystis jirovecii colonization in adult individuals of Turkish population. Biom Biostat Int J 2018; 7(4): 311-5.

40. Choukri F, Menotti J, Sarfati C, Lucet JC, Nevez G, Garin YJ, et al. Quantification and spread of Pneumocystis jirovecii in the surrounding air of patients with Pneumocystis pneumonia. Clin Infect Dis 2010; 51(3): 259-65.

41. Bartlett MS, Vermund SH, Jacobs R, Durant PJ, Shaw MM, Smith JW, et al. Detection of Pneumocystis carinii DNA in air samples: likely environmental risk to susceptible persons. J Clin Microbiol 1997; 35(10): 2511-3. 